\title{
Priority Primate Areas in Tanzania
}

\author{
Tim R.B. Davenport, Katarzyna Nowak and Andrew Perkin
}

\begin{abstract}
Priority Primate Areas are identified in Tanzania, mainland Africa's most important country for conservation of primates, on the basis of occupancy by globally rare, RedListed and range-restricted primate species and subspecies. We provide a comprehensive list and regional assessment of Tanzania's primate taxa, using IUCN Red List criteria, as well as the first national inventory of primates for 62 sites. The Priority Primate Areas, encompassing $102,513 \mathrm{~km}^{2}$, include nine national parks, one conservation area, seven game reserves, six nature reserves, 34 forest reserves and five areas with no official protection status. Primate species were evaluated and ranked on the basis of irreplaceability and vulnerability, using a combination of established and original criteria, resulting in a primate Taxon Conservation Score. Sites were ranked on the basis of summed primate scores. The majority (71\%) of Priority Primate Areas are also Important Bird Areas (IBAs), or part of an IBA. Critical subsets of sites were derived through complementarity analyses. Adequate protection of just nine sites, including six national parks (Kilimanjaro, Kitulo, Mahale, Saadani, Udzungwa and Jozani-Chwaka Bay), one nature reserve (Kilombero) and two forest reserves (Minziro and Mgambo), totalling $8,679 \mathrm{~km}^{2}$, would protect all 27 of Tanzania's primate species. The addition of three forest reserves (Rondo, Kilulu Hill and Ngezi) and two game reserves (Grumeti and Biharamulo), results in a list of 14 Priority Primate Areas covering $10,561 \mathrm{~km}^{2}(1.1 \%$ of Tanzania's total land area), whose conservation would ensure the protection of all 43 of Tanzania's species and subspecies of primates.
\end{abstract}

Keywords Conservation status, primates, priority sites, protected areas, Tanzania

This paper contains supplementary material that can be found online at http://journals.cambridge.org

\section{Introduction}

Since the mid 1990s a variety of priority setting concepts $\checkmark$ have been designed to guide policy and help reap maximum benefit in a world of limited conservation

Tim Davenport (Corresponding author) Wildlife Conservation Society, P.O. Box 922, Zanzibar, Tanzania. E-mail: tdavenport@wcs.org

Katarzyna Nowak Udzungwa Elephant Project, Iringa, Tanzania

ANDREW PERKIN c/o Tanzania Forest Conservation Group, Dar es Salaam, Tanzania

Received 14 July 2012. Revision requested 26 October 2012

Accepted 16 November 2012. First published online 17 July 2013. resources (Balmford, 2002; Caro, 2010; Gauthier et al., 2010). Often employing different taxa and/or criteria, these have been either coarse-scale and global in reach (e.g. Global Biodiversity Hotspots, Myers et al., 2000; Centres of Plant Diversity, WWF \& IUCN 1994-1997; Endemic Bird Areas, Stattersfield et al., 1998), or more fine-scale and regional, (e.g. Important Bird Areas, Fishpool \& Evans, 2001; Important Plant Areas, Anderson, 2002, Plantlife International, 2004; Important Mammal Areas, Linzey, 2002; Prime Butterfly Areas, van Swaay \& Warren, 2003). Others (e.g. Key Biodiversity Areas) are sites of global importance for conservation of biodiversity and yet aimed at the site-scale (Langhammer et al., 2007), with the irreplaceability and vulnerability of species the main criteria.

Tanzania is widely regarded as being the most important country in mainland Africa for biodiversity and biological endemism, with the continent's highest mountain, deepest lakes and two globally significant biodiversity hotspots, the Eastern Arc Mountains and the Albertine Rift (Burgess et al., 2004a, 2004b). However, Tanzania has the second highest rate of forest loss in sub-Saharan Africa (FAO, 2005) and, despite considerable conservation investment and a large amount of land nominally under protection, natural habitats and biodiversity continue to be lost at a significant rate (e.g. Rovero et al., 2012). For a developing nation of such global natural resource importance, priority setting is an essential conservation tool.

A range of general national-level priority setting analyses has been carried out in Tanzania. The African Mammal Databank undertook an environmental suitability and species occurrence analysis (Boitani et al., 1999), although extrapolations were based on species habitat suitability rather than species occupancy. No distinction was made at the subspecies level, and the extent and number of occupied protected areas was overestimated. The European Commission subsequently used these data to assess 31 protected areas in Tanzania for mammal, bird, amphibian and habitat irreplaceability (Hartley et al., 2007), and IUCN's Gap Analysis evaluated whether protected areas safeguard biodiversity and how much biodiversity falls outside them (Langhammer et al., 2007). More specifically, the Alliance for Zero Extinction (Ricketts et al., 2005) aimed to identify sites that contain at least $95 \%$ of a known population of one or more Critically Endangered or Endangered species. In Africa, 76 sites and 122 species were identified and Tanzania had the most (eight) Alliance for Zero Extinction sites, seven of which are based on amphibians. However, because of the nature of the Alliance for Zero Extinction process there is a bias towards sites that have been better investigated, and thus the list for Tanzania is neither topical 
nor complete. Currently, the Critical Ecosystem Partnership Fund is identifying Key Biodiversity Areas across the Eastern Afromontane Biodiversity Hotspot, including in Tanzania, but this work is not yet complete (BirdLife, 2012). At the species level there have been only two national analyses, the 77 Important Bird Areas of Tanzania (Baker \& Baker, 2002) and a partial identification of the nation's Important Plant Areas (McClean et al., 2006).

Primates are one of the most threatened and charismatic groups. The taxon is largely forest-dependent and Tanzania hosts eight endemic species. This represents $29 \%$ of its total primate species, a figure second only to Madagascar. Usually, it is the rare primate species that are less well studied, and this rarity is attributed to ecological specialization (Doherty \& Harcourt, 2004). In Tanzania, however, the two rarest species are not obligate specialists (Davenport et al., 2010; Nowak \& Lee, 2011) and as little is known about their distribution and conservation status as about that of the more common species. With the exception of a species list recently constructed as part of a photographic atlas of East African primates (De Jong \& Butynski, 2012) and a few site-specific primate lists (e.g. Rovero et al., 2009), Tanzania lacks a complete annotated list of its species (and subspecies/races) of diurnal and nocturnal primates, or a nationwide dataset of primate distribution and status. We provide here the first complete annotated list of Tanzanian primates, including diurnal and nocturnal species and subspecies. We also present a novel concept synonymous with Important Bird Areas, which we have called Priority Primate Areas, based on our compilation and comprehensive nationwide analysis of distributions and status. We identify these Priority Primate Areas to facilitate a focus on the range-restricted and threatened primate species and subspecies that will most benefit from conservation at the site-level. The intention is to quantify at a national scale the immediacy and precedence of threats to a group that has both considerable conservation relevance and charismatic appeal, thus identifying conservation gaps, providing 'watch lists' of priority sites and taxa using globally consistent criteria (Langhammer et al., 2007), and ensuring there is an objective, empirical and ranked plan to protect all of Tanzania's primates.

Specifically, we aim to (1) identify major populations and subpopulations of all primate species and subspecies in Tanzania, (2) rank species and subspecies according to their irreplaceability, vulnerability and conservation status (and anticipating future taxonomic change), (3) identify priority sites for conservation of primates on the basis of number of species present and rank, (4) provide a minimum critical list of sites whose protection would ensure the conservation of all of Tanzania's primates, (5) complement other taxaspecific analyses such as Important Bird Areas, (6) identify gaps in knowledge and conservation at a national scale, thus limiting duplication of conservation effort, and (7) provide a concept (Priority Primate Areas) that could be adopted internationally to prioritize implementation of the conservation of primate taxa. Primates are often flagship species (Caro, 2010); by identifying and quantifying priority sites for primates in Tanzania we hope to ameliorate resource allocation problems facing government and conservation organizations (Rondinini et al., 2006; Wilson et al., 2006) and focus conservation attention on Tanzania's unique primate fauna and the habitats in which they dwell.

\section{Methods}

\section{Species list}

A full species list of the diurnal and nocturnal primates of Tanzania was drawn up (Table 1). We followed the taxonomy of Grubb et al. (2003), and referred to Groves (2007) for Lophocebus johnstoni, Kingdon (1997) and Groves (2005) for Cercocebus sanjei, Davenport et al. (2006) for Rungwecebus kipunji, Groves (2001, 2005) for Chlorocebus pygerythrus, and Rahm (1970), Napier (1985) and Kingdon (1997) for Colobus angolensis sharpei. Primate taxonomy is developing, occasionally contentious, and compounded by concepts such as superspecies and clines, and by personal interpretation. It is not our intention here to enter into taxonomic debate. Tanzanian primates also experience high levels of hybridization, such as between the baboons Papio anubis and Papio cynocephalus on the Tanzania-Kenya border (Alberts \& Altmann, 2001) and the several inter- and intraspecific Cercopithecine hybrid zones (Detwiler et al., 2005), including Cercopithecus mitis albogularis and Cercopithecus mitis stuhlmanni in Ngorongoro and Lake Manyara, and Cercopithecus ascanius schmidti and Cercopithecus mitis doggetti in Gombe National Park (Detwiler, 2002). Although we recognize the presence of hybrids we did not include them in the analysis. We recognize two forms of Galagoides rondoensis, based on recent data (Perkin et al., unpubl. data).

\section{Species scores}

For each species and subspecies IUCN (2012b) proscriptions were applied. Following IUCN (2003) we also made assessments of the extinction risk of Tanzanian national populations of species and subspecies, as such evaluations were previously lacking. We thus assigned regional Red List categories to all Tanzanian taxa if the national status merited a classification higher than the global status (Table 1). Nationwide primate distributions were compiled from the literature, online databases, local expert knowledge and personal observations from our combined experience in Tanzania. Databanks included the IUCN Red List (IUCN, 2012b), the Primate Information Network factsheets (Primate Info Net, 2011), the African Mammals Databank (1999), 
TABLE 1 List of primate species and subspecies in Tanzania, with their Red List status at the global (IUCN, 2012b) and national levels (see text for sources). Endemic taxa are in bold (note that national and global assessments are the same when a taxon is endemic).

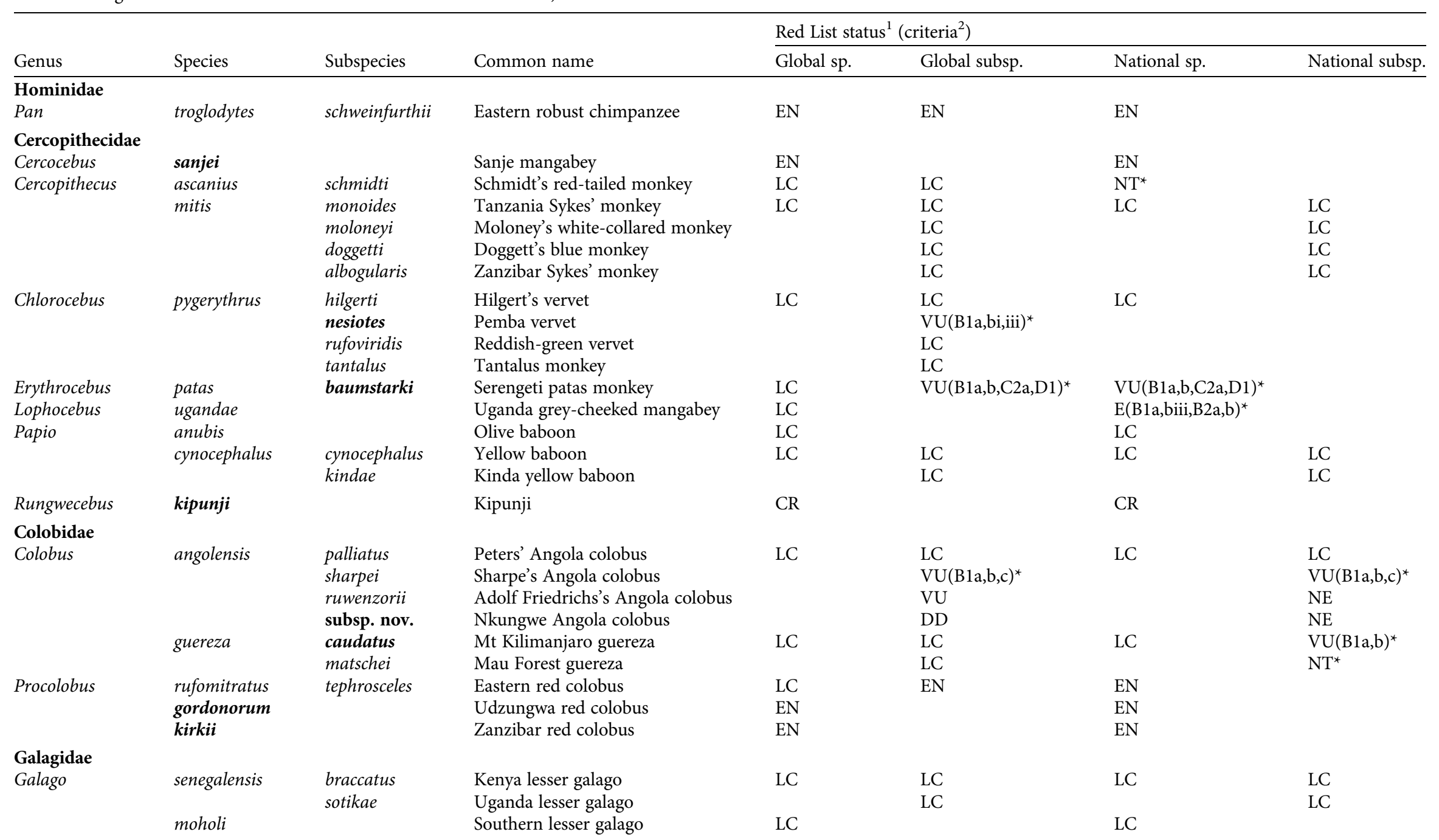




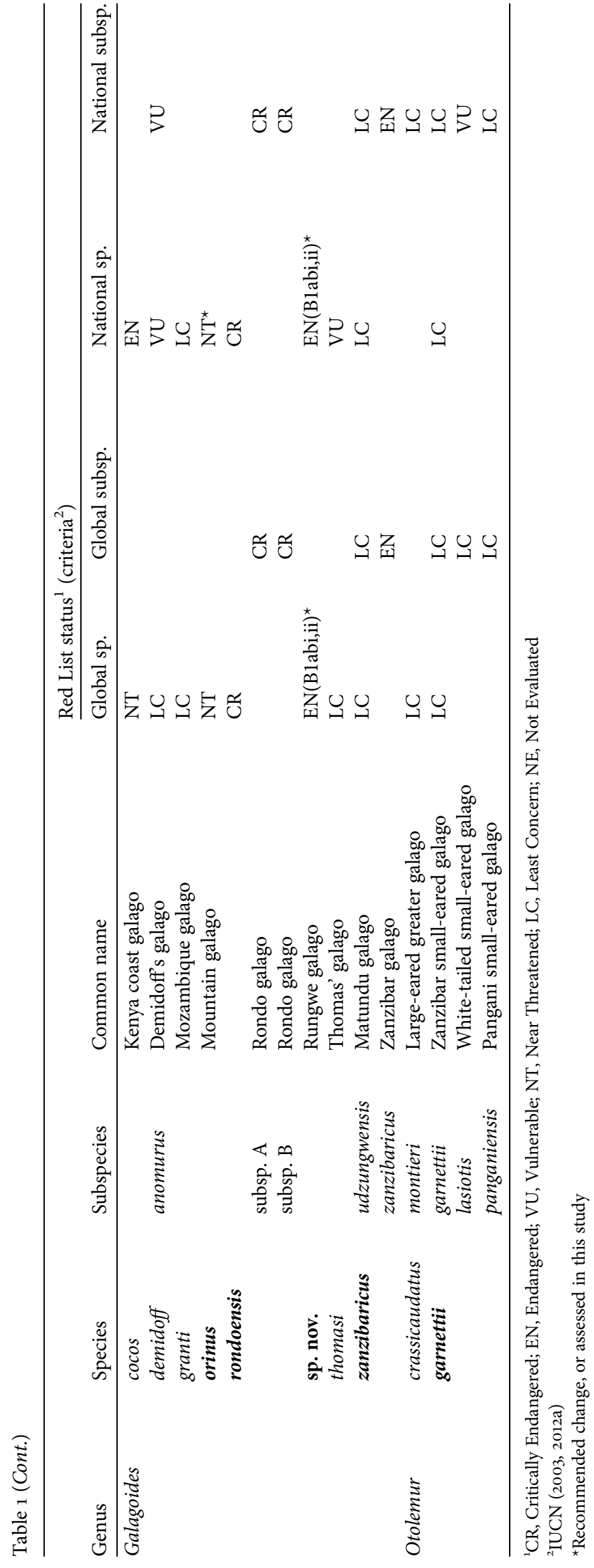

the Tanzania Mammal Atlas Project (2013), the Pictorial Guide to Living Primates (2013), Tanzania National Parks websites and grey literature, although these mainly provided extent of occurrence estimates rather than occupancy.

Site list

A list of discrete sites in which species occur was compiled (Fig. 1). This followed the Alliance for Zero Extinction definition (Ricketts et al., 2005): 'an area with a definable boundary within which the character of habitats, biological communities, and/or management issues have more in common with each other than they do with those in adjacent areas.' Thus, sites such as Tongwe East (Forest Reserve) and Ugalla River (Game Reserve), and Kitulo (National Park) and Mt Rungwe (Nature Reserve) were treated separately, although contiguous, because of their different protected area status and hence management. Protected area data came from Protected Planet (2013), the Tanzania Ministry of Natural Resources and Tourism, and Tanzania National Parks. Areas to which species were introduced (Rubondo Island for Pan troglodytes and Colobus guereza, and Ngezi Forest, Pemba, for Procolobus kirkii), were not included although we recognize that these sites may contribute to species' conservation and genetic and behavioural diversity.

\section{Taxon conservation score}

To rank sites it was first necessary to assign conservation scores to each taxon so that a summed score based on taxon presence could be applied. The taxon conservation score is a sum of a taxon's irreplaceability and vulnerability. For irreplaceability we modified the index used by the European Community (Hartley et al., 2007), calculating $1 / n$ (maximum $=1)$, where $\mathrm{n}=$ the number of sites in which a taxon occurs. To this site occupancy score we added a value reflecting the percentage of a taxon's total range that falls within Tanzania (maximum $=2.5$; Table 2 ); this gives a proxy for percentage of the total population within Tanzania, data that are unavailable for most taxa. Thus taxon irreplaceability score $=(1 / n)+(\%$ range score $)$. We calculated a taxon vulnerability score using global Red List data (IUCN, 2012b) and our recommended Tanzanian Red List status (maximum $=4$; Table 3 ), and the current population trend for each taxon. The latter was quantified according to whether the Tanzanian population is decreasing (0.5), stable or assumed stable (0), increasing (-0.5) or unknown $(-0.25)$. Thus vulnerability score $=$ Red List score + population trend score. Summing the scores of taxon irreplaceability and vulnerability produces an overall taxon conservation score (maximum total $=8$ ). 


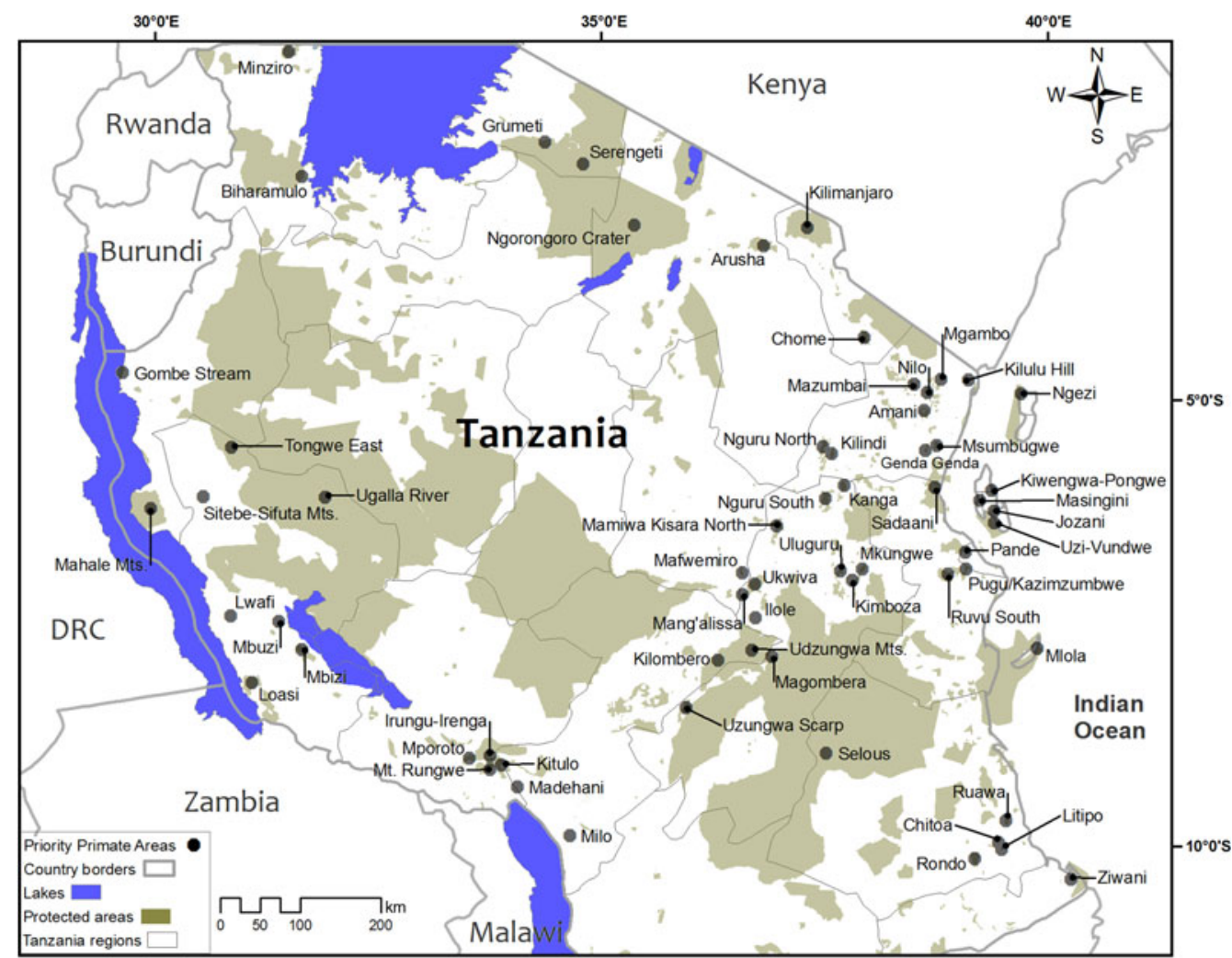

FIG. 1 Location of the 62 sites considered in the ranking analysis of Priority Primate Areas.

TABLE 2 Scores assigned to the percentage of the total range of a primate species or subspecies that falls within Tanzania, for the calculation of the taxon conservation score (see text for details).

\begin{tabular}{lll}
\hline$\%$ of range & Species & Subspecies \\
\hline 100 & 2.50 & 1.25 \\
$>50$ & 2.00 & 1.00 \\
$20-50$ & 1.50 & 0.75 \\
$5-20$ & 1.00 & 0.50 \\
$<5$ & 0.50 & 0.25 \\
\hline
\end{tabular}

\section{Site scores}

A matrix was compiled of the 62 sites identified (Fig. 1) and occupancy by primates (Supplementary Table $\mathrm{S}_{1}$ ). The taxon conservation scores for primates at each site were summed, producing total site scores for nocturnal, diurnal and all (combined nocturnal and diurnal) species and all taxa (Supplementary Tables $S_{2} \& S_{3}$, respectively). Sites were then ranked according to their taxon scores: all species, nocturnal species, diurnal species, all taxa, nocturnal taxa and diurnal taxa. To derive a ranked list of Priority Primate Areas two simple complementarity analyses were performed, one by taxa frequency and the other by site rank. For the former we began with the site in each category that had the highest number of taxa and then added the next site that would add more taxa. This was continued until a list of Priority Primate Areas for species and taxa had been
TABLE 3 Scores assigned to the global Red List status (IUCN, 2012b) or our recommended Tanzanian Red List status of primate species or subspecies (Table 1), for the calculation of the taxon conservation score (see text for details). The highest possible score for each taxon was applied.

\begin{tabular}{llllll}
\hline & \multicolumn{2}{l}{ Global } & & \multicolumn{2}{c}{ Tanzania } \\
\cline { 2 - 3 } Red List status & Species & Subspecies & & Species & Subspecies \\
\hline Critically & 4 & 2 & 1 & 0.5 \\
$\quad$ Endangered & & & & \\
Endangered & 3 & 1.5 & 0.75 & 0.375 \\
Vulnerable & 2 & 1 & 0.5 & 0.25 \\
Near Threatened & 1 & 0.5 & 0.25 & 0.125 \\
Least Concern & 0 & 0 & 0 & 0
\end{tabular}

produced. For the latter we began with the site that ranked highest and subsequent complementary sites were added consecutively from the site rank list that added more species (Howard et al., 2000; Brugiere, 2012).

\section{Results}

We recognize 27 species of primates in Tanzania (15 diurnal and 12 nocturnal species) and 43 taxa (26 diurnal and 17 nocturnal) including subspecies (Table 1). Of these, four are endemic diurnal primate species (C. sanjei, R. kipunji, Procolobus gordonorum and P. kirkii), four are endemic nocturnal species (Galagoides orinus, G. rondoensis, 
TABLE 4 The comparative ranking of each primate species based on the taxon conservation score (maximum $=8$; see text for details).

\begin{tabular}{cll}
\hline Rank & Species & Score \\
\hline 1 & R. kipunji & 7.33 \\
2 & G. rondoensis & 7.13 \\
3 & C. sanjei & 6.50 \\
4 & P. kirkii & 6.33 \\
5 & P. gordonorum & 6.24 \\
6 & G. sp. nov. & 6.20 \\
7 & P. troglodytes & 4.17 \\
8 & G. orinus & 4.07 \\
9 & G. cocos & 3.50 \\
10 & L. ugandae & 3.25 \\
11 & G. zanzibaricus & 2.54 \\
12 & G. thomasi & 2.50 \\
13 & P. rufomitratus & 2.45 \\
$14=$ & E. patas & 2.00 \\
$14=$ & G. demidoff & 2.00 \\
16 & G. moholi & 1.75 \\
17 & G. granti & 1.60 \\
$18=$ & C. angolensis & 1.53 \\
$18=$ & O. garnettii & 1.53 \\
20 & C. mitis & 1.52 \\
21 & C. guereza & 1.25 \\
22 & G. senegalensis & 1.11 \\
23 & C. ascanius & 1.08 \\
$24=$ & P. cynocephalus & 1.02 \\
$24=$ & C. pygerythrus & 1.02 \\
26 & O. crassicaudatus & 0.53 \\
27 & P. anubis & 0.11 \\
\hline & & \\
\hline & &
\end{tabular}

Galagoides sp. nov. and Galagoides zanzibaricus), and four are endemic diurnal subspecies (Chlorocebus pygerythrus nesiotes, Erythrocebus patas baumstarki, Colobus angolensis subsp. nov. and Colobus guereza caudatus). The list includes two species that are categorized on the IUCN Red List as Critically Endangered, five as Endangered, two as Near Threatened and 18 as Least Concern (IUCN, 2012b). At the subspecies level two are categorized as Critically Endangered, three as Endangered, four as Vulnerable, one as Data Deficient and 19 as Least Concern (IUCN, 2012b). At the national level two species are categorized as Critically Endangered, eight as Endangered, three as Vulnerable, two as Near Threatened and 11 as Least Concern, and at national subspecies level, two as Critically Endangered, one as Endangered, four as Vulnerable, one as Near Threatened, two as Not Evaluated and 13 as Least Concern (IUCN, 2012b). We assigned putative Red List categories (IUCN, 2003) for 11 taxa; the relevant justifications are given in Table 1.

The comparative rankings of each taxon are illustrated in Tables 4-5. The taxon conservation scores produced the same top six primates irrespective of whether the analysis was at the species or taxon level. These were R. kipunji, G. rondoensis, C. sanjei, P. gordonorum, P. kirkii and Galagoides sp. nov. Of the 62 sites identified as being of
TABLE 5 The comparative ranking of each primate taxon (i.e. species or subspecies) based on the taxon conservation score (maximum $=8$; see text for details).

\begin{tabular}{|c|c|c|}
\hline Rank & Taxon & Score \\
\hline 1 & R. kipunji & 7.33 \\
\hline 2 & C. sanjei & 6.50 \\
\hline $3=$ & P. kirkii & 6.33 \\
\hline $3=$ & P. gordonorum & 6.25 \\
\hline 5 & G. rungwe sp. nov. & 6.20 \\
\hline 6 & G. zanzibaricus zanzibaricus & 4.50 \\
\hline 7 & P. troglodytes schweinfurthi & 4.42 \\
\hline 8 & G. orinus & 4.07 \\
\hline 9 & G. rondoensis subsp. nov. B & 3.83 \\
\hline 10 & G. rondoensis subsp. nov. A & 3.70 \\
\hline $11=$ & C. pygerythrus nesiotes & 3.50 \\
\hline $11=$ & G. cocos & 3.50 \\
\hline 13 & L. ugandae & 3.25 \\
\hline 14 & C. angolensis subsp. nov. & 2.75 \\
\hline 15 & P. rufomitratus tephrosceles & 2.70 \\
\hline 16 & G. zanzibaricus udzungwensis & 2.55 \\
\hline $17=$ & C. angolensis ruwenzorii & 2.50 \\
\hline $17=$ & G. thomasi & 2.50 \\
\hline $19=$ & E. patas baumstarcki & 2.25 \\
\hline $19=$ & G. demidoff anomurus & 2.25 \\
\hline 21 & O. garnettii lasiotis & 2.00 \\
\hline $22=$ & C. angolensis sharpei & 1.75 \\
\hline $22=$ & C. guereza caudatus & 1.75 \\
\hline $22=$ & G. senegalensis sotikae & 1.75 \\
\hline $22=$ & G. moholi & 1.75 \\
\hline 26 & C. guereza matschiei & 1.63 \\
\hline 27 & G. granti & 1.60 \\
\hline 28 & O. garnettii panganiensis & 1.28 \\
\hline 29 & P. cynocephalus kindae & 1.25 \\
\hline 30 & C. ascanius schmidti & 1.08 \\
\hline 31 & P. cynocephalus cynocephalus & 1.03 \\
\hline 32 & C. mitis doggetti & 1.00 \\
\hline 33 & O. garnettii garnettii & 0.95 \\
\hline 34 & C. pygerythrus hilgerti & 0.89 \\
\hline $35=$ & C. mitis monoides & 0.88 \\
\hline $35=$ & G. senegalensis braccatus & 0.88 \\
\hline 37 & C. mitis moloneyi & 0.84 \\
\hline 38 & C. pygerythrus rufoviridis & 0.83 \\
\hline 39 & C. angolensis palliatus & 0.79 \\
\hline 40 & C. mitis albogularis & 0.78 \\
\hline 41 & C. pygerythrus tantalus & 0.54 \\
\hline 42 & O. crassicaudatus montieri & 0.53 \\
\hline 43 & P. anubis & 0.11 \\
\hline
\end{tabular}

importance for conservation of primates 57 are officially or nominally protected (nine national parks; six nature reserves; 34 forest reserves, including four proposed nature reserves; seven game reserves; and one conservation area). The other five sites are either privately managed or have no protection status.

On application of the taxon conservation scores to the 62 sites, a matrix was drawn up illustrating the Priority Primate Areas across Tanzania according to all diurnal and 

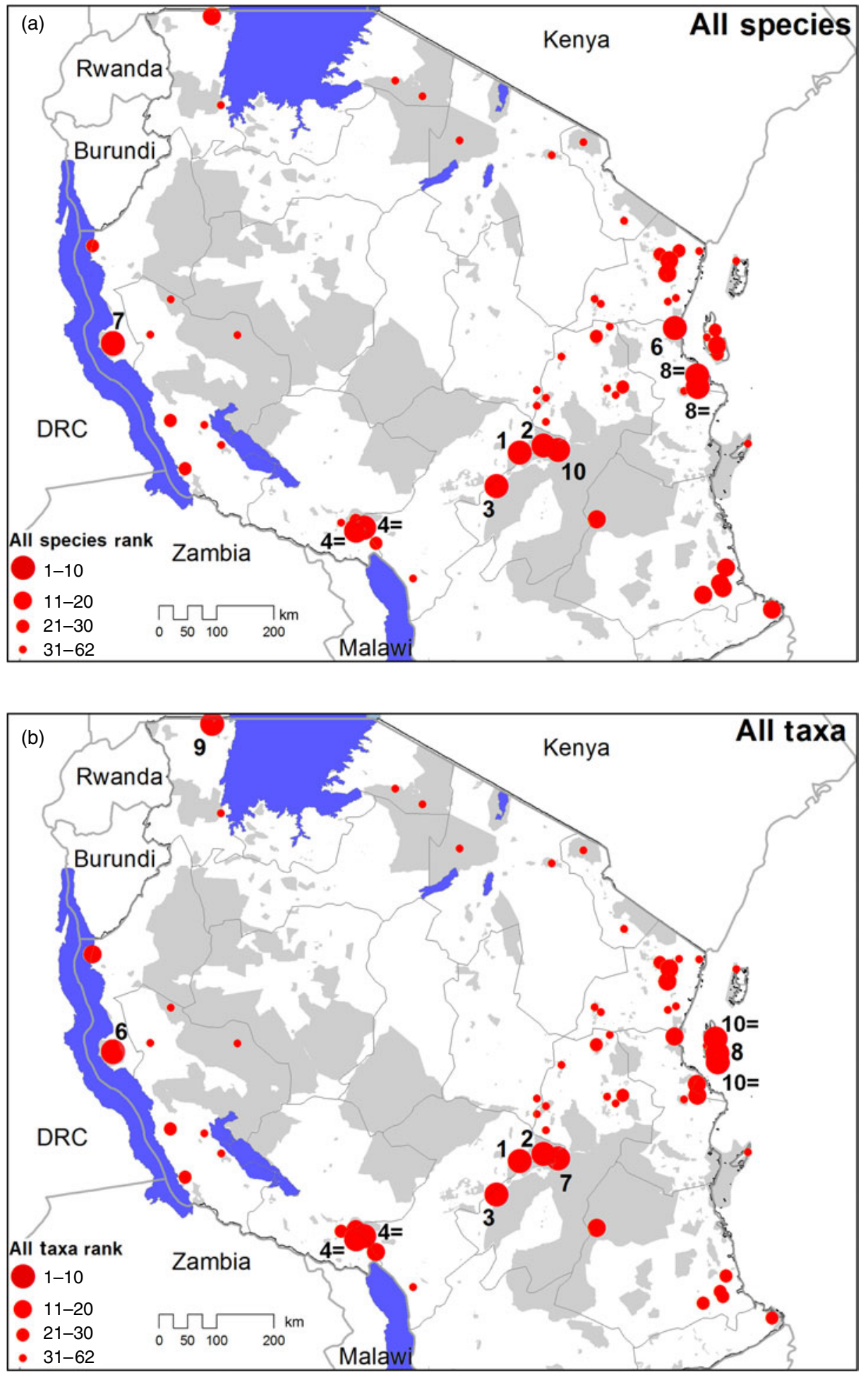

FIg. 2 Top-ranking sites for (a) all primate species and (b) all taxa (i.e. species and subspecies). All species: 1, Kilombero Nature Reserve $^{\star} \dagger ;$ 2, Udzungwa Mts National Park †; 3, Uzungwa Scarp Forest Reserve†; $4=$, Mt Rungwe Nature Reserve ${ }^{\star}+; 4=$, Kitulo National Park ${ }^{\star} \dagger ;$ 6, Saadani National Park; 7, Mahale National Park; $8=$, Pande $\mathrm{GR}^{\star} \dagger ; 8=$, Pugu/ Kazimzumbwe Forest Reserve ${ }^{\star} \dagger$; 10, Magombera $\dagger$. All taxa: $1-5$, as above; 6, Mahale National Park; 7, Magombera; 8, Jozani-Chwaka Bay National Parkt; 9, Minziro Forest Reserve; $10=$, KiwengwaPongwe Forest Reserve†; 10=, Uzi and Vundwe Islands $\dagger$.

${ }^{\star}$ Critically Endangered species; †endemic species present. nocturnal species and all diurnal and nocturnal taxa (Supplementary Tables $\mathrm{S}_{2}-\mathrm{S}_{3}$ ). When all primates are considered, either at the species level or species and subspecies level, the sites that emerged to be most important are Kilombero Nature Reserve, Udzungwa Mountains National Park and Uzungwa Scarp Forest Reserve, with Kitulo National Park and Mt Rungwe Nature Reserve in joint fourth place (Fig. 2). If diurnal and nocturnal primates are treated separately, Mahale Mountains National Park is placed fourth for diurnal taxa (Fig. 3). The nocturnal primates produced a different assessment. At both the species and all taxa levels, Saadani National Park, Pande Game Reserve, and Pugu/Kazimzumbwe, Chitoa, Litipo, Rondo, Ruawa and Ziwani Forest Reserves all illustrated the 

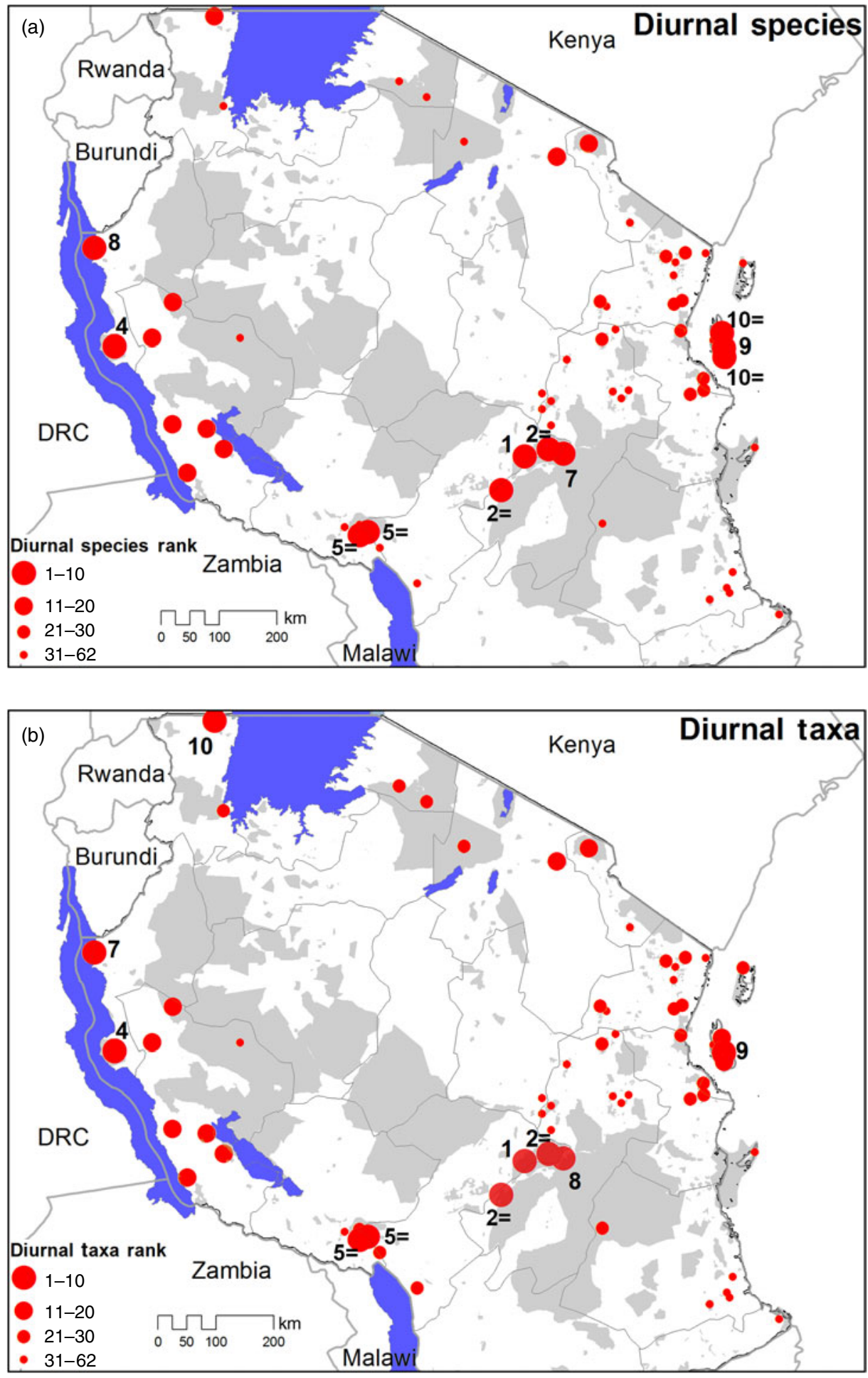

FIG. 3 Top-ranking sites for (a) diurnal primate species and (b) taxa (i.e. species and subspecies). Diurnal species: 1 , Kilombero Nature Reserve ${ }^{\star} \uparrow ; 2=$, Udzungwa Mts National Park†; $2=$, Uzungwa Scarp Forest Reservet; 4, Mahale National Park; $5=$, Mt Rungwe Nature Reserve $^{\star}+; 5=$, Kitulo National Park $^{\star} \dagger$; 7, Magombera $†$; , Gombe National Park; 9, Jozani-Chwaka Bay National Park $\dagger ; 10=$, Kiwengwa-Pongwe Forest Reservet; $10=$, Uzi/Vundwe Islands $\dagger$. Diurnal taxa: $1-5=$, as above; 7, Gombe National Park; 8, Magombera; 9, Jozani-Chwaka Bay National Park; 10, Minziro Forest Reserve.

${ }^{\star}$ Critically Endangered species; †endemic species present.

importance of Tanzania's coastal forests for galago taxa (Fig. 4).

To derive an applied and ranked list of priority areas for conservation of primates, two sets of Priority Primate Areas were determined based on the two complementarity analyses. For both the taxa frequency analysis and the site rank analysis, a list of nine sites (with possible alternatives) was identified for the 27 primate species, and 14 sites (with alternatives) for the 43 primate taxa (Tables $6-7$ ). Seven Priority Primate Areas were identified separately for the 15 diurnal species, eight for the 12 nocturnal species, 11 for the 26 diurnal taxa, and 10 for the 17 nocturnal taxa. 

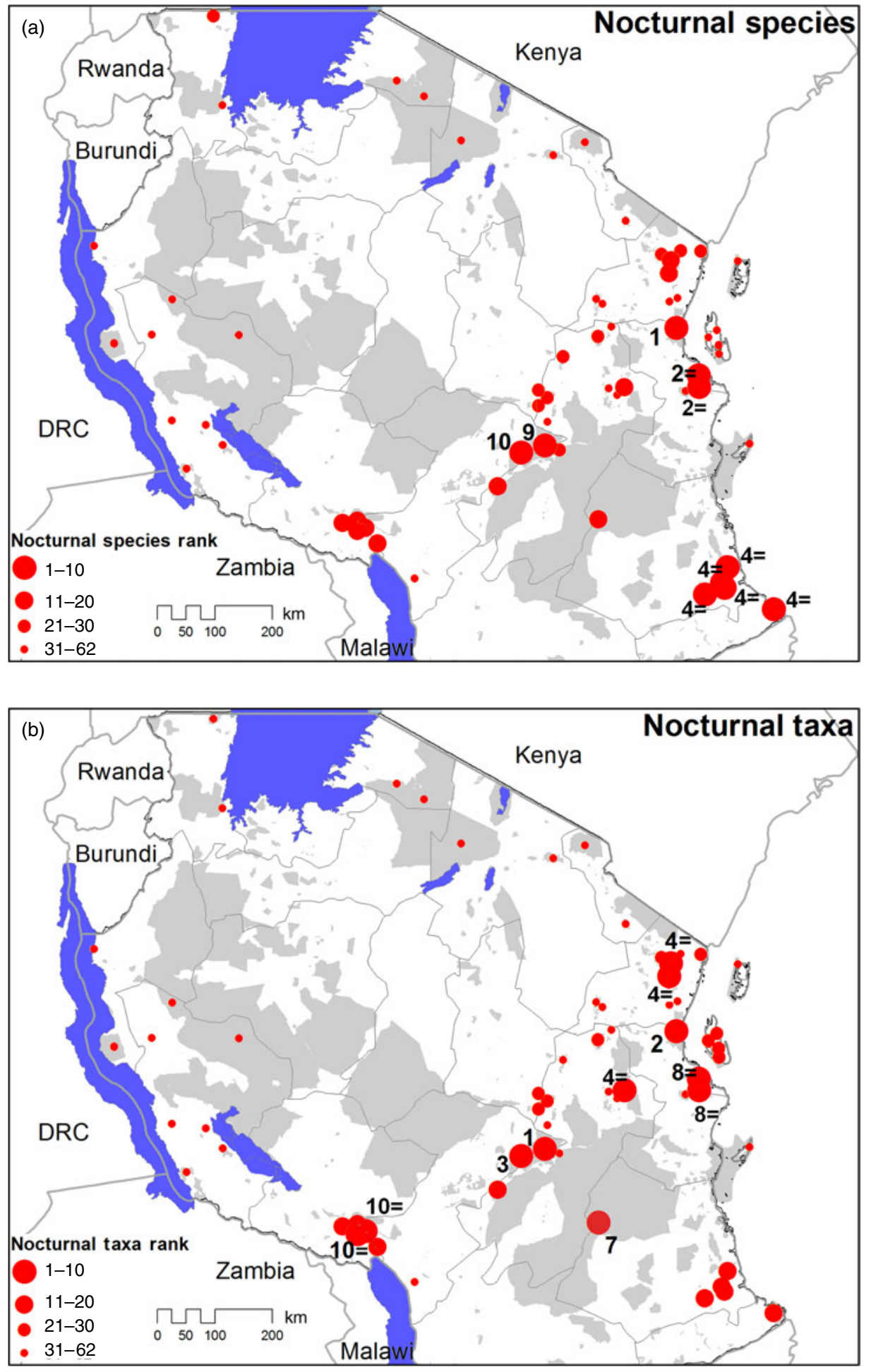

FIg. 4 Top-ranking sites for

(a) nocturnal primate species and (b) taxa (i.e. species and subspecies). Nocturnal species: 1 , Saadani National Park; $2=$, Pande $\mathrm{GR}^{\star} \dagger ; 2=\mathrm{Pugu} /$ Kazimzumbwe Forest Reserve ${ }^{\star}+; 4=$, Ruawa Forest Reserve; $4=$, Chitoa Forest Reserve; $4=$, Litipo Forest Reserve $^{\star} \dagger ; 4=$, Rondo Forest Reserve $^{x} \dagger ; 4=$, Ziwani Forest Reserve $^{\star}+$; 9, Udzungwa Mts National Park†; 10, Kilombero Nature Reserve†. Nocturnal taxa: 1, Udzungwa Mts National Park; 2, Saadani National Park; 3, Kilombero Nature Reserve; $4=$, Amani Forest Reserve; $4=$, Mkungwe Forest Reserve; $4=$, Nilo Nature Reserve; 7, Selous GR; $8=$, Pande GR; $8=$, Pugu/ Kazimzumbwe Forest Reserve; $10=$, Mt Rungwe Nature Reserve $\dagger$ $10=$, Kitulo National Park $\dagger$.

${ }^{\star}$ Critically Endangered species; †endemic species present.

\section{Discussion}

Given that endemism of primates in Tanzania is $29.6 \%$ at species level and $28.6 \%$ at species and subspecies level combined, with the highest number of threatened primate taxa in mainland Africa, the country is of global conservation significance. However, Tanzania still faces substantial challenges, with a growing human population, ever pressing needs for development and growth, and an increasingly fragmented and human-dominated landscape. Prioritization of conservation interventions is thus of particular importance for a nation with such a responsibility. Because of their diversity, broad appeal and taxonomic tractability, birds have often been used as 
TABLE 6 Minimum critical set of Priority Primate Areas, based on complementarity analyses (see text for further details), for all, diurnal and nocturnal species. The sites are those that would at a minimum need to be protected to conserve at least one population of each of Tanzania's primate species.

\begin{tabular}{|c|c|c|}
\hline Rank & Area $^{*}$ & $\begin{array}{l}\text { No. of } \\
\text { species }\end{array}$ \\
\hline \multicolumn{3}{|c|}{ All species } \\
\hline 1 & Kilombero NR & 10 \\
\hline 2 & Udzungwa Mts NP & 2 \\
\hline 3 & Kitulo NP or Mt Rungwe NR & 1 \\
\hline 4 & Saadani NP & 1 \\
\hline 5 & Mahale Mountains NP & 5 \\
\hline 6 & Jozani-Chwaka Bay NP & 1 \\
\hline 7 & Minziro FR & 4 \\
\hline 8 & Mgambo FR & 1 \\
\hline \multirow[t]{2}{*}{9} & Kilimanjaro NP & 2 \\
\hline & Total & 27 \\
\hline \multicolumn{3}{|c|}{ Diurnal species } \\
\hline 1 & Kilombero NR & 6 \\
\hline 2 & $\begin{array}{c}\text { Udzungwa Mts NP or } \\
\text { Uzungwa Scarp FR }\end{array}$ & 1 \\
\hline 3 & Mahale Mts NP & 3 \\
\hline 4 & Gombe Stream NP & 1 \\
\hline 5 & Jozani-Chwaka Bay NP & 1 \\
\hline 6 & Minziro FR & 1 \\
\hline \multirow[t]{2}{*}{7} & Arusha NP or Kilimanjaro NP & 2 \\
\hline & Total & 15 \\
\hline \multicolumn{3}{|c|}{ Nocturnal species } \\
\hline 1 & Sadaani NP & 4 \\
\hline 2 & $\begin{array}{l}\text { Chitoa FR or Litipo FR or Rondo } \\
\text { FR or Ruawa FR or Ziwani FR }\end{array}$ & 1 \\
\hline 3 & Udzungwa Mts NP & 1 \\
\hline 4 & Kilombero NR & 1 \\
\hline 5 & Selous & 1 \\
\hline 6 & Kitulo NP or Mt Rungwe NR & 1 \\
\hline 7 & Kilulu Hill FR or Mgambo FR & 1 \\
\hline \multirow[t]{2}{*}{8} & Minziro FR & 2 \\
\hline & Total & 12 \\
\hline
\end{tabular}

${ }^{*}$ NR, Nature Reserve; NP, National Park; FR, Forest Reserve

effective indicators of biodiversity and habitat health (Howard et al., 1998), although cross-taxon congruence has been less reliable, in part because of birds' greater mobility (Tsushabe et al., 2006). Despite their charismatic qualities and evolutionary proximity to humans, primates have been less of a focus for priority setting and less often used as surrogate taxa for broader conservation needs. This priority setting for primates is the first such national analysis, and offers an objective, quantifiable protocol for the identification of Priority Primate Areas. We have developed this method both to provide the means to replicate the process of prioritizing sites important for primates in other countries and to help focus national conservation priorities in Tanzania.

There were a number of challenges, and compromises made, in designing this system, the foremost being how best

Table 7 Minimum critical set of Priority Primate Areas, based on complementarity analyses (see text for further details), for all, diurnal and nocturnal taxa (i.e. species and subspecies). The sites are those that would at a minimum need to be protected to conserve at least one population of each of Tanzania's primate taxa.

\begin{tabular}{clr}
\hline Rank & Area & $\begin{array}{r}\text { No. } \\
\text { taxa }\end{array}$ \\
\hline All taxa & \\
1 & Kilombero NR \\
2 & Udzungwa Mts NP & 10 \\
3 & Kitulo NP or & 3 \\
& Mt Rungwe NR & 2 \\
4 & Mahale Mountains NP & 8 \\
5 & Jozani-Chwaka Bay NP & 5 \\
6 & Minziro FR & 5 \\
7 & Saadani NP & 1 \\
8 & Chitoa FR or Litipo FR or & 1 \\
& Rondo FR or Ruawa FR & \\
9 & or Ziwani FR & 3 \\
10 & Kilimanjaro NP & 1 \\
11 & Mgambo FR & 1 \\
12 & Kilulu Hill FR & 1 \\
13 & Grumeti GR & 1 \\
14 & Biharamulo GR & 1 \\
& Ngezi FR & 43
\end{tabular}

\section{Diurnal taxa}

1

2

3

4

5

6

7

8

9

10

11

\section{Nocturnal taxa}

1

2

3

4

5

6

7

8

9

10
Kilombero NR

Udzungwa Mts NP or

Uzungwa Scarp FR

Mahale Mts NP

Kitulo NP or Mt Rungwe NR

Gombe Stream

Jozani-Chwaka Bay NP

Minziro FR

Tongwe East GR

Arusha NP or

Kilimanjaro NP

Grumeti GR

Ngezi FR

Total

Udzungwa Mts NP

Sadaani NP

Kilombero NR

Selous GR

Kitulo NP or Mt Rungwe NR

Chitoa FR or Litipo FR or

Rondo FR or Ruawa FR or

Ziwani FR

Kilulu Hill FR

Jozani NP or Masingini FR

or Uzi-Vundwe

or Kiwengwa-Pongwe

Minziro FR

Biharamulo GR

Total
No. of

axa

3

2

5

5

1

3

1

1

1

3

6

2

6

1

1

3

2

1

2

1

1

26

${ }^{\star}$ NR, Nature Reserve; NP, National Park; FR, Forest Reserve; GR, Game Reserve 
to define a site. We concluded that an area must have a definable boundary within which the character of habitats, biological communities, and/or management issues have more in common with each other than they do with those in adjacent areas. Conservation must be pragmatic. However, it is clear that prioritization of forest sites can change as lesser known areas are investigated (Burgess et al., 2007; Davenport et al., 2007). That notwithstanding, the correlation between site rankings and degree of survey effort (Doggart et al., 2006) is less of an issue with smaller taxonomic groups such as primates.

There are a number of sites in Tanzania where primate species have been introduced, notably Rubondo Island in Lake Victoria ( $P$. troglodytes and $C$. guereza), Ngezi Forest on Pemba Island and Masingini Forest on Zanzibar (Unguja) Island (P. kirkii). We made the decision not to include sites where species had been introduced, although in some instances this was difficult to prove. For example, it is not known whether vervets are indigenous to Zanzibar but there is no irrefutable evidence to the contrary. It is the case that introductions are different to reintroductions on the basis that reintroductions are a valid conservation tool. However, although $P$. kirkii were introduced to Masingini (Silkiluwasha, 1981) it is unclear if they were there formerly. Therefore, we omitted P. troglodytes and C. guereza in Rubondo and P. kirkii in Ngezi and, as we have no evidence of their former presence in Masingini, we omitted them at this site too. For the same reason we retained vervets in the analysis.

Our study highlighted eight species of particular conservation concern in Tanzania: R. kipunji, G. rondoensis, C. sanjei, P. kirkii, P. gordonorum, Galagoides sp. nov., $P$. troglodytes and $G$. orinus. We also assigned a threat category to a number of taxa that had not previously been designated (Table 1). However, our main aim was to identify all key primate sites in Tanzania, to prioritize conservation intervention and facilitate the role of primates as flagship or umbrella species (Caro, 2011) for the conservation of key habitats. The list of Priority Primate Areas identified differs according to whether species and subspecies, and diurnal or nocturnal taxa are considered (Supplementary Tables S2-S3). Top-ranking sites for diurnal taxa are in the Udzungwa Mountains, Southern Highlands, Zanzibar archipelago, two forested western national parks (Gombe and Mahale), and the north-western forest of Minziro within the Guinea-Congo biome. The top-ranking sites for nocturnal taxa, although also including the Udzungwa Mountains and Southern Highlands, predominantly include sites in the coastal forest zone from the East Usambaras in the north to the south-eastern Lindi forests, as well as the Selous Game Reserve in south-central Tanzania. There is, therefore, little overlap in the importance of sites for diurnal and nocturnal primate species, suggesting that the former cannot be used as a surrogate for the latter.
Forests are of most relevance for conservation of primates and are ranked accordingly in our analyses. This is in contrast to many Important Bird Areas, where savannah and wetland habitats are often equally important. However, 44 of the 62 Priority Primate Areas are also Important Bird Areas or parts of them. Highest ranking in the Priority Primate Areas are the species-rich forests of the Eastern Arc Mountains, the Southern Highlands, including Mt Rungwe and Livingstone Mountains, and the northern ranges incorporating Kilimanjaro, Mt Meru (Arusha National Park) and Ngorongoro. However, because of their soils, rainfall and drainage, forested areas are also important for agriculture and forest products, and are therefore often zones of the greatest human-primate conflict.

Based on recent reports of accelerating forest loss, sites needing particular conservation attention include the forest reserves of Chome, East Usambaras, Ilole, Mbizi, Milo, Uzungwa Scarp and Ziwani, and the unprotected forests of Magombera, Mbuzi, Uzi and Vundwe Islands (Davenport et al., 2007; Nowak et al., 2009; Nowak \& Lee, 2011; Rovero et al., 2010, 2012). The coastal forests of Pugu and Kazimzumbwe (two of four forests in the Dar es Salaam greenbelt; Monga \& Gwegime, 2011) are subjected to high human disturbance because of their proximity to Dar es Salaam and the city's demand for charcoal and timber. However, these forests are potentially manageable as an urban recreational and educational asset. In general however, the charcoal industry is growing rapidly and is a major threat to forests nationwide. Remote locations, such as the Lindi forests (Perkin et al., 2011), are safer from these pressures but often receive little management attention as a result.

Of the 62 Priority Primate Areas only five (Ilole, Madehani, Magombera, Mbuzi and Uzi and Vundwe Islands) have no official protection status. However, this gives a misleading impression because few forest reserves in Tanzania are actively managed in any way. Game Reserve management usually depends on the zeal of individual concession holders. Thus not all of the Priority Primate Areas we propose are equal in terms of conservation management. Although a national park should be considered safer than a forest reserve, few protected areas are managed adequately and adjacent human density can be an important factor determining conservation success (Wittemeyer et al., 2008).

The critical subset of Priority Primate Areas (Tables 6-7) attempts to rationalize through complementarity the full list of areas and demonstrates how selective targeting could conserve Tanzania's primates. The protection of just nine sites, totalling $8,679 \mathrm{~km}^{2}$, would protect all 27 of Tanzania's primate species. This subset includes six national parks (Kilimanjaro, Kitulo, Mahale, Saadani, Udzungwa and Jozani-Chwaka Bay), one nature reserve (Kilombero) and 
two forest reserves (Minziro and Mgambo). The addition of just three forest reserves (Rondo, Kilulu Hill and Ngezi) and two game reserves (Grumeti and Biharamulo) results in a list of 14 Priority Primate Areas comprising 10,561 km (1.1\%) of Tanzania's total land area, the conservation of which would ensure the protection of all 43 of Tanzania's primate taxa (species and subspecies). We believe therefore that adoption of the Priority Primate Area system as a guiding concept could help focus efforts to conserve primates in Tanzania, and also globally.

\section{Acknowledgements}

This study was funded by the Wildlife Conservation Society. We are grateful to the following people for information and assistance: Liz Baker, Simon Bearder, Tom Butynski, Tim Caro, Anthony Collins, Daniela De Luca, Kate Detwiler, Nike Doggart, Richard Estes, Charles Foley, Trevor Jones, Yvonne de Jong, Alex Lobora, Jonathan Kingdon, Sophy Machaga, Noah Mpunga, Arafat Mtui, Alex Piel, the late Alan Rodgers, Francesco Rovero, Bill Stanley, Fiona Stewart and Tom Struhsaker.

\section{References}

African Mammals Databank (1999) Http://www.gisbau.uniroma1. it/amd [accessed 16 May 2013].

Alberts, S.C. \& Altmann, J. (2001) Immigration and hybridization patterns of yellow and anubis baboons in and around Amboseli, Kenya. American Journal of Primatology, 53, 139-154.

Anderson, S. (2002) Identifying Important Plant Areas. Plantlife International, London, UK. Http://hirc.botanic.hr/HBoD/IPA/ Identifying-IPAs-in-Europe.pdf [accessed 10 May 2013].

BAKer, N. \& BAKer, E. (2002) Important Bird Areas in Tanzania. Wildlife Conservation Society of Tanzania, Dar es Salaam, Tanzania.

Balmford, A. (2002) Selecting sites for conservation. In Conserving Bird Biodiversity: General Principles and their Application (eds K. Norris \& D.J. Pain), pp. 75-104. Cambridge University Press, Cambridge, UK.

Birdife International. (2012) Ecosystem Profile: Eastern Afromontane Biodiversity Hotspot. Critical Ecosystem Partnership Fund. BirdLife International, Cambridge, UK.

Boitani, L., Corsi, F., De Biae, A., D'inzillo Carranza, I., Ravagli, M., Reggiani, G. et al. (1999) A Databank for the Conservation and Management of the African Mammals. Institute of Applied Ecology, Rome, Italy.

BRUGIÈRE, D. (2012) Identifying priority areas for the conservation of antelopes in the Republic of Guinea, West Africa, using the complementarity approach. Oryx, 46, 253-259.

Burgess, N.D., Butynski, T.M., Cordeiro, N.J., Doggart, N., FJeldsÅ, J., Howell, K.M. et al. (2007) The biological importance of the Eastern Arc Mountains of Tanzania and Kenya. Biological Conservation, 134, 209-231.

Burgess, N., D'amico Hales, J., Underwood, E., Dinerstein, E., Olson, D., Itoua, I. et al. (2004b) Terrestrial Ecoregions of Africa and Madagascar: A Continental Assessment. Island Press, Washington, DC, USA.
Burgess, N., Lovett, J., Rodgers, A., Kilahama, F., Davenport, T.R.B. \& Butynski, T. (2004a) Eastern Arc Mountains and Southern Rift. In Hotspots Revisited (eds R. Mittermeier, P. Gil, M. Hoffmann, J. Pilgrim, T. Brooks, C. Mittermeier, J. Lamoreux \& G. da Fonseca), pp. 245-255. Conservation International/CEMEX, Mexico City, Mexico.

CARO, T. (2010) Biodiversity: need for balanced reports of solutions and failures. Nature, 465, 289.

Caro, T. (2011) Conservation by Proxy: Indicator, Umbrella, Keystone, Flagship, and Other Surrogate Species. Island Press, Washington, DC, USA.

Davenport, T.R.B., De Luca, D.W., Bracebridge, C.E., Machaga, S.J., Mpunga, N.E., Kibure, O. \& Abeid, Y. (2010) Diet and feeding patterns in the kipunji (Rungwecebus kipunji) in Tanzania's Southern Highlands: a first analysis. Primates, 51, 213221.

Davenport, T.R.B., Mpunga, N.E. \& Machaga, S.J. (2007) Census and conservation assessment of the red colobus (Procolobus rufomitratus tephrosceles) on the Ufipa Plateau, southwest Tanzania: newly-discovered, threatened and extinct populations. Primate Conservation, 22, 97-105.

Davenport, T.R.B., Stanley, W.T., Sargis, E.J., De Luca, D.W., Mpunga, N.E., Machaga, S.J. \& Olson, L.E. (2006) A new genus of African monkey, Rungwecebus: morphology, ecology, and molecular phylogenetics. Science, 312, 1378-1381.

De Jong, Y.A. \& Butynski, T.M. (2012) The primates of East Africa: country lists and conservation priorities. African Primates, 7, 135155 .

Detwiler, K.M. (2002) Hybridization between red-tailed monkeys (Cercopithecus ascanius) and blue monkeys (C. mitis) in East African forests. In The Guenons: Diversity and Adaptation in African Monkeys (eds M.E. Glenn \& M. Cords), pp. 79-97. Kluwer Academic/Plenum, New York, USA.

Detwiler, K.M., Burrell, A.S. \& Jolly, C.J. (2005) Conservation implications of hybridization in African Cercopithecine monkeys. International Journal of Primatology, 26, 661-684.

Doggart, N.H., Perkin, A., Kiure, J., Fjeldsa, J., Poynton, J. \& Burgess, N.D. (2006) Changing places: how the results of new fieldwork in the Rubeho Mountains influence conservation priorities in the Eastern Arc Mountains of Tanzania. African Journal of Ecology, 44, 134-144.

Doherty, D.A. \& Harcourt, A.H. (2004) Are rare primate taxa specialists or simply less studied? Journal of Biogeography, 31, 57-61.

FaO (Food and Agricultural Organization of the United NAtions) (2005) FAO Statistical Database 2005. Http://faostat.fao. org/ [accessed 16 May 2013].

Fishpool, L.D.C. \& Evans, M.I. (2001) Important Bird Areas in Africa and Associated Islands: Priority Sites for Conservation. BirdLife Conservation Series No. 11. BirdLife International, Cambridge, UK.

Gauthier, P., Debussche, M. \& Thompson, J.D. (2010) Regional priority setting for rare species based on a method combining three criteria. Biological Conservation, 143, 1501-1509.

Groves, C.P. (2001) Primate Taxonomy. Smithsonian Institution Press, Washington, DC, USA.

Groves, C.P. (2005) Order Primates. In Mammal Species of the World. A Taxonomic and Geographic Reference. 3 rd edition (eds D.E. Wilson \& D.M. Reeder), pp. 111-184. Johns Hopkins University Press, Baltimore, USA.

Groves, C.P. (2007) The taxonomic diversity of the Colobinae of Africa. Journal of Anthropological Sciences, 85, 7-34.

Grubb, P., Butynski, T.M., Oates, J.F., Bearder, S.K., Disotell, T.R., Groves, C.P. \& Struhsaker, T.T. (2003) Assessment of the diversity of African primates. International Journal of Primatology, 24, 1301-1357. 
Hartley, A., Nelson, A., Mayaux, P. \& Grégoire, J-M. (2007) The Assessment of African Protected Areas. JRC Scientific and Technical Reports. Office for Official Publications of the European Communities, Luxembourg. Http://bioval.jrc.ec.europa.eu/APAAT/ [accessed 10 May 2013].

Howard, P.C., Davenport, T.R.B., Kigenyi, F.W., Viskanic, P., Baltzer, M.C., Dickinson, C.J. et al. (2000) Protected area planning in the tropics: Uganda's national system of forest nature reserves. Conservation Biology, 14, 858-875.

Howard, P.C., Viskanic, P., Davenport, T.R.B., Kigenyi, F.W., Baltzer, M.C., Dickinson, C.J. et al. (1998) Complementarity and the use of indicator groups for reserve selection in Uganda. Nature, $394,472-475$.

IUCN (2003) Guidelines for Application of IUCN Red List Criteria at Regional Levels v. 3.o. IUCN Species Survival Commission, Gland, Switzerland, and Cambridge, UK.

IUCN (2012a) IUCN Red List Categories and Criteria Version 3.1. 2nd edition. IUCN, Gland, Switzerland, and Cambridge, UK.

IUCN (2012b) The IUCN Red List of Threatened Species v. 2012.1. Http://www.iucnredlist.org [accessed 5 July 2012].

Kingdon, J. (1997) The Kingdon Field Guide to African Mammals. Princeton University Press, Princeton, USA

Langhammer, P. F., Bakarr, M.I., Bennun, L.A., Brooks, T.M., Clay, R.P., Darwall, W. et al. (2007) Identification and Gap Analysis of Key Biodiversity Areas. IUCN, Gland, Switzerland.

LinZeY, A.V. (2002) Important Mammal Areas: a US pilot project. In Society for Conservation Biology, 16th Annual Meeting: Programme and Abstracts. Durrell Institute of Conservation and Ecology, Canterbury, UK.

Mcclean, C.J., Doswald, N., Kuper, W., Sommer, J.H., Barnard, P. \& Lovett, J.C. (2006) Potential impacts of climate change on Sub-Saharan African plant priority area selection. Diversity and Distributions, 12, 645-655.

Monga, E. \& Gwegime, J. (2011) Dar is being stripped of its greenbelt: we need action now! The Arc Journal, 26, 1-3. Http://www.tfcg.org/ pdf/Arc\%20Journal\%2026\%20FINAL.pdf [accessed 10 May 2013].

Myers, N., Mittermeier, R.A., Mittermeier, C.G., Da FonsecA, G.A. \& Kent, J. (2000) Biodiversity hotspots for conservation priorities. Nature, 403, 853-858.

Napier, P. H. (1985) Catalogue of Primates in the British Museum (Natural History) and Elsewhere in the British Isles, Part 2: Family Cercopithecidae, Subfamily Colobinae. British Museum (Natural History), London, UK.

NowaK, K. \& LeE, P.C. (2011) Demographic structure of Zanzibar red colobus populations in unprotected coral rag and mangrove forests. International Journal of Primatology, 32, 24-45.

Nowak, K., Perkin, A. \& Jones, T. (2009) Update on Habitat Loss and Conservation Status of the Endangered Zanzibar Red Colobus on Uzi and Vundwe Islands. Unpublished Report for Department of Commercial Crops, Fruits and Forestry, Zanzibar, Tanzania. Http:// www.primate.org/publications.htm [accessed 1o May 2013].

Perkin, A., Samuel, B., \& Gwegime, J. (2011) Going for gold in the Noto Plateau, SE Tanzania. The Arc Journal, 26, 14-16. Http://www. tfcg.org/pdf/Arc\%20Journal\%2026\%2oFINAL.pdf [accessed 10 May 2013].

Pictorial Guide to Living Primates (2013) Http://www. alltheworldsprimates.org [accessed 16 May 2013].

Plantlife International. (2004) Identifying and Protecting the World's Most Important Plant Areas: A Guide to Implementing Target 5 of the Global Strategy for Plant Conservation. Plantlife International, Salisbury, UK.
Primate Info Net (2011) Http://pin.primate.wisc.edu/factsheets [accessed 16 May 2013].

Protected Planet (2013) Http://www.protectedplanet.net [accessed 16 May 2013].

RAнм, U. H. (1970) Ecology, zoogeography, and systematics of some African forest monkeys. In Old World Monkeys (eds. J.R. Napier \& P.H. Napier), pp. 589-626. Academic Press, New York, USA, and London, UK.

Ricketts, T.H., Dinerstein, E., Boucher, T., Brooks, T.M., Butchart, S.H.M., Hoffmann, M. et al. (2005) Pinpointing and preventing imminent extinctions. Proceedings of the National Academy of Sciences of the United States of America, 102, 18497-18501.

Rondinini, C., Wilson, K.A., Biotani, L., Grantham, H. \& Possingham, H.P. (2006) Tradeoffs of different types of species occurrence data for use in systematic conservation planning. Ecology Letters, 9, 1136-1145.

Rovero, F., Marshall, A.R., Jones, T. \& Perkin, A. (2009) The primates of the Udzungwa Mountains, Tanzania: diversity, ecology and conservation. Journal of Anthropological Sciences, 87, 93-126.

Rovero, F., Mtui, A., Kitegile, A. \& Nielsen, M. (2012) Hunting or habitat degradation? Decline of primate populations in Udzungwa Mountains, Tanzania: an analysis of threats. Biological Conservation, 146, 86-96.

Rovero, F., Mtui, A., Kitegile, A., Nielsen, M. \& Jones, T. (2010) Uzungwa Scarp Forest Reserve in Crisis: An Urgent Call to Protect one of Tanzania's Most Important Forests. Unpublished Report. Dar es Salaam, Tanzania.

Silkiluwasha, F. (1981) The distribution and conservation status of the Zanzibar red colobus. African Journal of Ecology, 19, 187-194.

Stattersfield, A.J., Crosby, M.J., Long, A.J. \& Wege, D.C. (1998) Endemic Bird Areas of the World. BirdLife Conservation Series 7. BirdLife International, Cambridge, UK.

Tanzania Mammal Atlas Project (2013) Http://www. tanzaniamammals.org [accessed 16 May 2013].

Tsushabe, H., Kalema, J., Byaruhanga, A., Asasira, J., Ssegawa, P., Balmford, A. et al. (2006) A nationwide assessment of the biodiversity value of Uganda's IBA Network. Conservation Biology, 20, 85-99.

Van Swaay, C.A.M. \& Warren, M.S. (2003) Prime Butterfly Areas of Europe: an initial selection of priority sites for conservation. Journal of Insect Conservation, 10, 5-11.

Wilson, K.A., Mcbridge, M.F., Bode, M. \& Possingham, H.P. (2006) Prioritizing global conservation efforts. Nature, 440, 337-40.

Wittemeyer, G., Elsen, P., Bean, W.T., Burton, A.C.O. \& Brashares, J.S. (2008) Accelerated human population growth at protected area edges. Science, 321, 123-126.

WWF \& IUCN (1994-97) Centres of Plant Diversity: A Guide and Strategy for Their Conservation. WWF \& IUCN, Gland, Switzerland, and Cambridge, UK.

\section{Biographical sketches}

Tim Daven PORT's research interests include biogeography, exploration, herpetology, human impacts, orchidology, primatology and protected areas. KAте NowAK studies primate and elephant behaviour and the use of refuge habitats in flooded and montane forests. AndRew PERKIN studies the phylogeography, bioacoustics and taxonomy of galagos with a focus on forested landscapes, and hyrax and elephant shrew diversity. 